\title{
Marguerite de Valois, Mémoires et Discours
}

\section{Michele Mastroianni}

\section{(2) OpenEdition}

\section{Journals}

\section{Edizione digitale}

URL: http://journals.openedition.org/studifrancesi/34562

DOI: 10.4000/studifrancesi.34562

ISSN: 2421-5856

\section{Editore}

Rosenberg \& Sellier

\section{Edizione cartacea}

Data di pubblicazione: 1 novembre 2005

Paginazione: 406

ISSN: 0039-2944

\section{Notizia bibliografica digitale}

Michele Mastroianni, «Marquerite de Valois, Mémoires et Discours», Studi Francesi [Online], 146 (XLIX |

II) | 2005, online dal 30 novembre 2015, consultato il 18 avril 2021. URL: http://

journals.openedition.org/studifrancesi/34562 ; DOI: https://doi.org/10.4000/studifrancesi.34562

Questo documento è stato generato automaticamente il 18 avril 2021. 


\title{
Marguerite de Valois, Mémoires et Discours
}

\author{
Michele Mastroianni
}

\section{NOTIZIA}

MARGUERITE DE VALOIS, Mémoires et Discours, édition ÉLIANE VIENNOT, Saint-Étienne, Publications de l’Université de Saint-Étienne, 2004, pp. 229.

1 Éliane Viennot, che aveva curato l'edizione critica della opere di Marguerite de Valois la reine Margot della tradizione romantica - (cfr. Mémoires et autres écrits, 1574-1614, Paris, Champion, 1999), ripropone i Mémoires e due altri testi in prosa, la Déclaration du roi de Navarre, scritta dalla regina nel 1574 per conto del marito, il futuro Enrico IV, colpevole di un colpo di stato, e il Discours sur l'excellence des femmes, un breve scritto in forma di lettera, composto negli ultimi anni di vita, che si inserisce nella filière di quella querelle des femmes che da due secoli era dibattuta nella cultura francese. Il pregio della presente edizione, oltre a quello di essere accompagnata da un'agile ma densa introduzione, è di rendere economicamente accessibile - agli studenti universitari in particolare - l'edizione critica di un testo di grande interesse per la ricostruzione delle ore più drammatiche delle guerre di religione e degli intrighi, politici e amorosi, della corte di Enrico III. 